\title{
A strategy for seed management with climate change
}

\author{
by B.S.P. Wang ${ }^{1}$ and E.K. Morgenstern²
}

\begin{abstract}
While climate change has been generally accepted by the forestry community, we are still searching for ways and means to alleviate its impact. We still have to collect seeds, for example, to support continued reforestation programs. To provide some guidance for meeting the changing environments, we felt it is important to review the current seed management strategy, discuss species adaptability and seed source as well as collection, handling, germination, treatment and storage. Further, we give recommendations to minimize the impact of climate change.
\end{abstract}

Key words: adaptation, seed source, collection, handling, storage, dormancy treatment, germination, genetic and physiological quality, seedling production

\section{RÉSUMÉ}

Même si les changements climatiques sont généralement acceptés par la communauté forestière, nous sommes encore à la recherche de solutions et de moyens d’en diminuer les conséquences. Nous avons encore à récolter les semences, par exemple, pour maintenir les programmes de reboisement. Afin d'obtenir un peu d'aide pour faire face aux environnements en voie de changement, nous considérons qu'il est important de réviser notre stratégie actuelle de gestion des semences, de discuter de la capacité d'adaptation des espèces et des sources de semence ainsi que de la collecte, la manipulation, la germination, le traitement et l'entreposage. De plus, nous suggérons des recommandations visant à minimiser l'impact des changements climatiques.

Mots clés : adaptation, source de semence, collecte, manipulation, entreposage, traitement de dormance, germination, qualité génétique et physiologique, production de semis

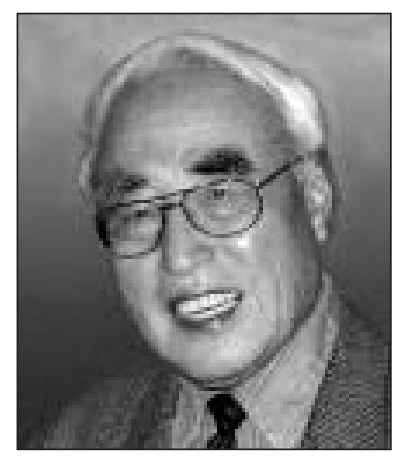

B.S.P. Wang

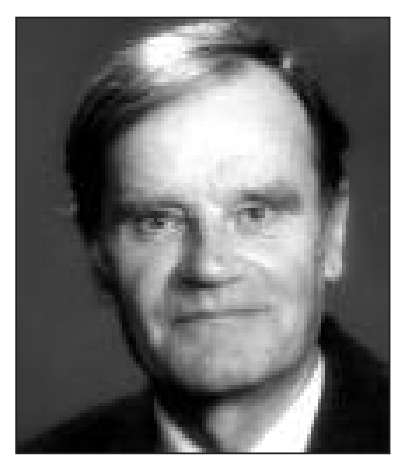

E.K. Morgenstern

\section{Introduction}

The forestry community has generally accepted the fact that a change of climate is underway and that its impact will be significant. Research has been initiated on how to alleviate or reduce its impact. We assume that the change will come about in a gradual manner and that our forest tree species possess the potential to adapt to a changing environment. There is some uncertainty about the actual degree and direction of this change, although various predictions have been made (Forestry Chronicle 81 [5], 2005). Nevertheless, regeneration

by planting and seeding will continue, and to deal with new conditions, changes in the strategy of seed management must be anticipated and implemented. These changes will affect all stages of the regeneration system from seed collection and storage to seedling production. In this paper, we review the current practices in cone/fruit collection, handling and processing, storage, and treatment to overcome dormancy for germination and early seedling production; and discuss the importance of incorporating the control of genetic and physiological quality into the current practice with a view to meet the challenges of future changing environments.

\section{Adaptation}

Adaptation is defined as the evolutionary modification of characters by natural selection and other genetic processes to enhance the fitness of the organism considered (West-Eberhard 1992). For each species, therefore, the ability to adapt depends upon its genetic variation, which in turn is a function of its geographic range and its genetic system including mode of reproduction, mating system, chromosome factors, and prevailing genetic processes such as natural selection, migration, and inbreeding. (Stern and Roche 1974). For example, black spruce (Picea mariana [Mill.] BSP) is an outbreeding, wind-pollinated species that reproduces sexually or asexually by layering, and has a transcontinental range and

\footnotetext{
${ }^{1}$ Natural Resources Canada, Canadian Wood Fibre Centre, Canadian Forest Service, Petawawa Research Forest, P.O. Box 2000, Chalk River, Ontario K0J 1J0. E-mail: benwang@nrcan.gc.ca

${ }^{2}$ Former Research Scientist at Petawawa and retired Professor, University of New Brunswick, now at R.R. 7, Pembroke, Ontario K8H 6W8. Dr. Morgenstern passed away on December 31, 2008. A tribute to Kris is planned for the next issue of The Forestry Chronicle.
} 
great variability most typically expressed by a clinal variation pattern (Morgenstern 1969). In contrast, red pine (Pinus resinosa) is also a wind-pollinated species but reproduces only sexually, tolerates partial inbreeding, and has a limited natural range and less genetic variation (Morgenstern 1969, Mosseler et al.1992).

The complexity of the origin of genetic variation and adaptation suggests that control of seed origin based only on seed zones (i.e., climatic factors controlling natural selection) can be inadequate, at least for some species. For example, trembling aspen (Populus tremuloides) not only exhibits a clonal structure (Cheliak and Pitel 1984) but also variation in chromosome number (Heimburger 1968) as well as introgressive hybridization with largetooth aspen (Populus grandidentata) (Barnes 1961). Further, white spruce (Picea glauca) may be subject to inbreeding (Coles and Fowler 1976). Many other examples could be cited (Morgenstern 1996). Many characters or traits are involved in adaptation; for seed processing and handling, variation in some cone characters is important. For example, the cones of eastern white pine (Pinus strobus) require several winter months of post-harvest curing before seed extraction, while those from western North Carolina of the United States are ready in 7 days (Bonner 1986). Surprisingly, when Ontario eastern white pine (Lat. $46^{\circ} \mathrm{N}$; Long. $77^{\circ}-78^{\circ} \mathrm{W}$ ) were grown in the Liaoning Province of China (Lat. $39^{\circ} 00^{\prime}-42^{\circ} 06^{\prime} \mathrm{N}$; Long. $121^{\circ} 00^{\prime}-$ $124^{\circ} 57^{\prime} \mathrm{E}$ ), their first crop of cones required only a few days of post-harvest curing before seed processing (Jian Dong ${ }^{3}$, personal communication). It is possible that eastern white pine has a latent potential to adapt to the new environment, and a large amount of literature deals with the introduction of exotic species in many regions of the world, but this topic will not be considered here (Zobel and Talbert 1984). Johnsen et al. (2005) reported that Norway spruce (Picea abies) has developed a memory mechanism, regulating adaptive plasticity by photoperiod and temperature, which could counteract harmful effects of a rapidly changing climate.

\section{Source of Seed}

Natural stands and plantations regenerated from unimproved (wild) seed are the primary source of seed for species that have not been subjected to tree improvement programs. Before seed collections are made, it is useful to understand the variation pattern associated with the tree species. Any species that has a wide range distribution across several ecological regions is made up of several subpopulations or stands within each region that grow and develop in a similar manner. As a result of natural selection by a narrow range of climate and other physical and biological factors, and migration (gene exchange by pollen flight and seed dispersal), this similarity of physiological performance at the subpopulation level is maintained. At the same time, the variability within subpopulations or tree-to-tree variation is large because of, for example, environmental variation at the local level, and fluctuations in climate from year to year due to differences in winter temperature, length of the growing season, precipitation, and so on (Morgenstern 1996). Numerous provenance experiments have documented this type of occurrence and also demonstrated the possibility of transfer to neighbouring regions (Morgenstern 1996, Morgenstern et al. 2006).

\footnotetext{
${ }^{3}$ Liaoning Provincial Academy of Forestry in Shenyang, China.
}

Broadleaf species in this category present a special problem. Although seed collections have been made and many aspects of seed handling have been explored (Willan 1985, Schmidt 2000), their silvics and genetic variation are not well known. With some exceptions (e.g., the genera Populus and perhaps Betula) much more research is needed. This situation is critical for 2 reasons: 1 ) some of these species occur only in small remnant populations that are adapted to a narrow range of environments and are probably inbred, such as those in southern Ontario, and 2) they are not likely to benefit much from the opportunity of range extension (by natural regeneration or planting) because of a lack of genetic variation and adaptability. For these reasons genetic conservation assumes a most important role (Beardmore et al. 2006).

Seed collections in natural stands and plantations have to deal with the fact that often due to pollination of neighbouring trees, which may be related, a significant quantity of inbred seed is produced. This increases mortality and reduces the efficiency of the seed handling and seedling production process. More details on seed handling will be discussed later.

Seed orchards constitute the second major source of seed. In provinces where systematic selection programs have been conducted for several decades, large quantities of seed are now available that contribute greatly to reforestation programs - in some cases fulfilling requirements (Canadian Tree Improvement Association 2006). Orchard seed is generally of high genetic and physiological quality. The randomized layout of clones or individual trees in orchards reduces inbreeding, and cultivation practices such as irrigation, fertilization, and insect control enhance seed size (Kolotelo 2000) and seed vigour of some species (e.g., black spruce (unpublished data, Ron Smith and Ben Wang), although lodgepole pine (Pinus contorta) seed from British Columbia provincial seed orchards exhibited increased dormancy and required longer periods of moist chilling than seed from natural stands (Kolotelo 2000).

A series of seed orchards for each major ecological region assures the seed supply for many years to come, and offers considerable flexibility to meet the needs of a reforestation program in an age of climate change. The availability of many clones or genotypes also allows for continued selection and testing to develop more advanced seed producers for the future (Zobel and Talbert 1984).

\section{Cone/Fruit Collection and Handling}

The genetic and physiological quality of tree seeds is also affected by collection and handling, as this is the most important first step in the seed production process. In order to obtain seeds of high genetic quality seeds, genetic variability must be maintained by randomly collecting from an increased number of parent trees, uniformly distributed across the population only in good seed crop years. In the province of British Columbia, the minimum number of parent trees to be collected from a natural stand is 10 while the province of Alberta requires 30 for all tree species except aspen (Populus tremuloides) (Anon. 2004, Anon. 2005). However, one author suggested that the number of unrelated parent trees per population for ex situ conservation plantations is 50 to 100 (Theilade 2003). If these recommendations are considered to adequately conserve the diversity of a population, they could be acceptable criteria for incorporating into future cone/fruit collection to meet the uncertainty of climate change. 
Physiological seed quality is greatly affected by seed maturity when the highest seed quality is demonstrated by maximum germinability and vigour. Therefore, all available means of determining seed maturity such as specific gravity of cones, colour change of cones/fruits, and anatomical development of embryos and megagametophyte should be used to determine the proper timing of cone/fruit collection.

Following cone/fruit harvesting, it is essential to handle the collected cones/fruits carefully by maintaining the identity of the seed lots and by curing them by air-drying them in half-full burlap bags or in screen-bottomed trays in well-ventilated environments. This is especially vital for cones/fruits harvested prior to reaching full maturity (e.g., many conifers) to avoid possible injury from heating and moulding. Cones/fruits of some tree species such as the true firs (Abies spp.), white spruce (Picea glauca), and many subtropical tree species require post-harvest ripening for seeds to reach full maturity for maximum germination and vigour (Rediske and Nicholson 1965; Caron et al. 1990, 1993; Wang et al. 1995). For such species, special care is needed to fulfill their anatomical requirements in order to complete the maturation process. Wang (2002) reported that seed quality is influenced by the whole process of handling from cone/fruit collection through processing to storage, and all stages are inter-related. For example, if seeds are collected when immature, they are likely to be susceptible to injury during processing and difficult to store.

To prevent seed injury in seed processing, safe kiln-drying temperatures (Wang et al. 1992) and a moist de-winging technique must be applied to minimize seed losses. The current practice of grading and sizing should be discontinued in order to maintain genetic variability within the seed lots (Hellum 1976, Silen and Osterhaus 1979, Chaisurisri et al. 1992). Following processing, clean seeds should be tested for germination immediately and again before field sowing if they have been stored for a few years.

\section{Seed Storage}

Ageing is a natural and irreversible process; once seeds have reached their full maturity they are at the peak of their germinability and vigour. From that point on, their lifespan diminishes, although the rate of ageing depends on moisture content of the seed and storage conditions. According to Simpson et al. (2004) and Walters et al. (2004), orthodox seeds (tolerant to drying and subfreezing temperatures) can be stored for 100 years or longer in sealed containers at $-18^{\circ} \mathrm{C}$ to $-20^{\circ} \mathrm{C}$ with a low seed moisture content of $4 \%$ to $7 \%$ (Simpson et al. 2004, Walters et al. 2004). In addition, disturbance during long-term storage was identified as an important factor influencing seed storage life and could be minimized by using small containers to minimize such an effect (Simpson et al. 2004). For a continuous supply of seed for reforestation, a good seed inventory must be maintained with 5 to 10 years of reserve seed supply from as many major populations as possible across the species' natural range. It would be very important that the inventory should represent both major species populations and outlier populations (Aiken et al. 2007).

Treatment for Seed Germination and Early Development In order to maintain the genetic variability of seed lots, the most effective treatment should be applied to promote maximum germination and vigour of all seeds in a seedlot. To this end, the unique treatment of moist chilling or cold stratification has been found to be cost-effective and beneficial process to alleviate seed dormancy and enhance the rate and maximum germination, inducing natural repair mechanism, and reducing the sensitivity of seeds toward handling and microenvironmental conditions (Wang 1987, Wang and Berjak 2000). The beneficial effects of moist chilling on seed germination and early seedling development are especially significant when applied with extended periods for uniform seedling production in nurseries. This is especially important in container seedling production, where multiple-seed sowing should be avoided to maintain genetic diversity within the seed lots (El-Kassaby et al. 1992, El-Kassaby and Thomson 1996). Kolotelo (2000) revealed that seed orchard-produced lodgepole pine seeds required a longer period of moist chilling than that of natural stands due to increased dormancy. It is also important to make sure the moist chilling treatment is done properly, particularly with the maintenance of moisture content during the course of moist chilling (e.g., yellow-cedar [Chamaecyparis nootkatensis]) (Xia et al. 2002). Gosling and Broadmeadow (2005) suggest that if climate change brings longer, warmer fall temperatures, its impact will be detrimental to both shallow- and deep-dormant tree species in their regeneration.

\section{Recommendations}

Under the uncertain circumstances of climate change, cone/fruit collection operations need to be continued for scheduled reforestation requirements. However, we have to consider what the best way would be to harvest seeds to maintain strong adaptability and tolerance to a wide range of changing environments. We consider that the more diversified a population of a species is, the better the chance for its adaptability and survival in a changing environment. Forestry is a long-term investment and it pays to prepare the seeds for forestation with the most diversified genetic and physiological quality. We feel strongly that the following recommendations are essential for achieving this objective:

1. Collect seeds from 50 to 100 unrelated parent trees of major and peripheral populations only in good crop years to maintain high diversity and adaptability;

2. Time collection with all available techniques for the measurement of full seed maturity such as specific gravity, changing colour of cones/fruits, anatomical development, cone/fruit moisture content, etc.;

3. Provide cool and ventilated environments for proper curing of collected cones/fruits for continued maturation process and for species that require post-harvest ripening to ensure their full maturation process;

4. Collecting the temperate recalcitrant seeds (seeds that cannot tolerate drying below relatively low moisture content and sub-freezing temperature) such as silver maple (Acer saccharinum) and oaks (Quercus spp.) requires not only awareness of crop periodicity and seed maturity indices, but also maintenance of high seed moisture content (30\%-45\% fresh weight) to ensure maximum genetic and physiological quality;

5. Test seed germinability and vigour using standard methods immediately after processing and before sowing if the seeds have been stored for some years;

6. Condition seeds of orthodox storage behaviour to a moisture content of $4 \%$ to $7 \%$ of fresh weight and store them in 
sealed containers at $-18^{\circ} \mathrm{C}$ to $-20^{\circ} \mathrm{C}$ with minimum disturbance. For species with recalcitrant storage behaviour, seeds should be dried to relatively high moisture content (30\%-45\% fresh weight) and stored in aerated containers at near-freezing temperatures.

7. Always maintain 5 to 10 years of seed reserves for major reforestation species in the seed bank and continuously monitor their germinability and vigour.

\section{Acknowledgements}

We thank Dr. Darwin Burgess and Mr. Dale Simpson of the Canadian Forest Service for their constructive reviews of the manuscript. We also thank summer student Annabelle Martensen for reading the manuscript.

\section{References}

Aitken, S., B. Fady and M. Mimura. 2007. Conserving evolutionary potential: why priority should be placed on peripheral populations? In J.D. Simpson (ed.). Proceedings, Canada's Forests Enhancing productivity, protection and conservation, $30^{\text {th }}$ Meeting of the Canadian Tree Improvement Association, Charlottetown, Prince Edward Island, July 24-27, 2006, Part 2: 8 (Abstract).

Anon. 2004. Chief Forester's standards for seed use. British Columbia Ministry of Forests. 36 p.

Anon. 2005. Standards for tree improvement in Alberta. Land and Forest Division, Alberta Sustainable Resource Development, Edmonton, AB. 121 p.

Barnes, B.V. 1961. Hybrid aspens in the Lower Peninsula of Michigan. Rhodora 63: 311-324.

Beardmore, T., J. Loo, B. McAfee, C. Malouin and D. Simpson. 2006. A survey of tree species of concern in Canada: the role for genetic conservation. For. Chron. 82: 351-363.

Bonner, F.T. 1986. Cone storage and seed quality in eastern white pine (Pinus strobus L.). Tree Planters' Notes 37: 3-6.

Canadian Tree Improvement Association. 2006. J.D. Simpson ed. Proceedings of the $30^{\text {th }}$ Meeting of the Canadian Tree Improvement Association, Charlottetown, PEI, July 24-27, 2006, Part 1. Minutes and members report, 93 p; Part 2. Symposium, 77 p.

Caron, G.E., B.S.P. Wang and H.O. Schooley. 1990. Effect of tree spacing, cone storage, and prechilling on germination of Picea glauca seed. For. Chron. 66: 388-392.

Caron, G.E., B.S.P. Wang and H.O. Schooley. 1992. Variation in Picea glauca seed germination associated with the year of cone collection. Can. J. For. Res. 23: 1306-1313.

Chaisurisri, K., D.G.W. Edwards and Y.A. El-Kassaby. 1992. Genetic control of seed size and germination in Sitka spruce. Silvae Genet. 41: 348-355.

Cheliak, W.M. and J.A. Pitel. 1984. Electrophoretic identification of clones in trembling aspen. Can. J. For. Res. 14: 740-743.

Coles, J.F. and D.P. Fowler. 1976. Inbreeding in neighboring trees in two white spruce populations. Silvae Genet. 25: 29-34.

El-Kassaby, Y.A., D.G.W. Edwards and D.W. Taylor. 1992. Genetic control of germination parameters in Douglas-fir and its importance for domestication. Silvae Genet. 41: 48-54.

El-Kassaby, Y.A. and A.J. Thomson. 1996. Parental rank changes associated with seed biology and nursery practices in Douglas-fir. For. Sci. 42: 228-235.

Gosling, P. and M. Broadmeadow. 2005. Seed dormancy and climate change. In Forest Research, Annual Report and Accounts, 2004-2005. pp. 21. The Research Agency of the Forestry Commission, Edinburgh.

Heimburger, C. 1968. Poplar breeding in Canada. In Growth and utilization of poplars in Canada. pp.88-100. Can. For. Br. Pub. 1205.
Hellum, A.K. 1976. Grading seed by weight in white spruce. Tree Planters' Notes 27: 16-17, 23.

Johnsen, O., O.G. Daehlen, G. Ostreng and T. Skroppa. 2005. Daylength and temperature during seed reproduction interactively affect adaptive performance of Picea abies progenies. New Phytologist 168: 589-596.

Kolotelo, D. 2000. Cone and seed improvement program, BCMoF Tree Seed Centre. In N. Wilder, P. Byman and C. Hawkins (Tech. Coords.). Proceedings of the 2000 Forest Nursery Association of British Columbia, Sept. 18-21, 2000, Prince George, BC. pp. 9-21.

Morgenstern, E.K. 1969. Genetic variation in seedlings of Picea mariana (Mill.) BSP. I. Correlation with ecological factors. II. Variation patterns. Silvae Genet. 18: 151-167.

Morgenstern, E.K. 1996. Geographic variation in forest trees. UBC Press, Vancouver. 209 p.

Morgenstern, E.K., S. D'Eon and M. Penner. 2006. White spruce growth to age 44 in a provenance test at the Petawawa Research Forest. For. Chron. 82: 572-578.

Mosseler, A. K.N. Egger and G.A. Hughes. 1992. Low levels of genetic diversity in red pine confirmed by random amplified polymorphic DNA markers. Can. J. For. Res. 22: 1332-1337.

Rediske, J.H. and D.C. Nicholson. 1965. Maturation of Noble fir seed-a biochemical study. Weyerhaeuser For. Paper No. 2

Silen, R. and C. Osterhaus. 1979. Reduction of genetic base by sizing of bulked Douglas-fir seed lots. Tree Planters' Notes 30: 24-30.

Simpson, J.D., B.S.P. Wang and B.I. Daigle. 2004. Long-term storage of various Canadian hardwoods and conifers. Seed Sci. and Technol.32: 561-572.

Schmidt, L. 2000. Guide to handling of tropical and subtropical forest seed. Danida Forest Seed Centre, Krogeruvej 21, DK-3050 Humlebaek, Denmark. 511 p.

Stern, K. and L. Roche. 1974. Genetics of forest ecosystems. Springer Verlag, New York. 330 p.

Theilade, I. 2003. The role of ex situ conservation of trees in living stands. Guidelines \& Tech. Notes No. 64, Danida Forest Seed Centre, Humlebaek, Denmark. 11 p.

Walters, C., L.J. Wheeler and P.C. Stanwood. 2004. Longevity of cryogenically stored seeds. Cryobiology 48: 229-244.

Wang, B.S.P. 1987. The beneficial effects of stratification on tree seed germination. Proceedings, Nurserymen's Meeting, Dryden, ON, June 15-19, 1987. pp. 56-75. Ontario Min. of Natural Resources, Toronto, ON.

Wang, B.S.P. 2002. Control of seed quality in reforestation and afforestation. Proceedings, Tropical Forestry Symposium: The art and practice of conservation planting, September 24-29, 2001, Taipei, Taiwan, TFRI Extension Series No.145: 14-26.

Wang, B.S.P. and P. Berjak. 2000. Beneficial effects of moist chilling on the seeds of black spruce (Picea mariana [Mill.] B.S.P.). Ann. Bot. 86: $29-36$

Wang, B.S.P., B. Downie, S. Wetzel, D. Palamarek and R. Hamilton. 1992. Effects of cone scorching on germinability and vigour of lodgepole pine seeds in Alberta. Seed Sci. \& Technol. 20: 409-419.

Wang, B.S.P., L.P. Lin and C.T. Chien. 1995. Classification of storage behaviour of forest tree seeds. Bull. of the Taiwan Forest Research Institute (in Chinese with an English summary).

West-Eberhard, M.J. 1992. Adaptation: current usages. In Key words in evolutionary biology. Harvard University Press. pp. 13-18. Willan, R.L. 1985. A guide to forest seed handling. FAO Forestry Paper 20/2, FAO, Rome. 379 p.

Xia, J.H., D. Stewart and A.R. Kermode. 2002. Modified moist chilling treatments that promote germination and post-germinative reserve mobilization of different seed lots of yellow-cedar. Seed Sci. \& Technol. 30: 263-277.

Zobel, B. and J. Talbert. 1984. Applied forest tree improvement. Wiley \& Sons, New York. 505 p. 